\title{
Oidium longipes, A New Powdery Mildew Fungus on Petunia in the USA: A Potential Threat to Ornamental and Vegetable Solanaceous Crops
}

\author{
Levente Kiss and Tünde Jankovics, Plant Protection Institute of the Hungarian Academy of Sciences, H-1525 Bu- \\ dapest, P.O. Box 102, Hungary; Gábor M. Kovács, Eötvös Loránd University, Department of Plant Anatomy, H- \\ 1117 Budapest, Pázmány Péter sétány 1/C, Hungary; and Margery L. Daughtrey, Department of Plant Pathology, \\ Cornell University, Riverhead, NY 11901, USA
}

\begin{abstract}
Kiss, L., Jankovics, T., Kovács, G. M., and Daughtrey, M. L. 2008. Oidium longipes, a new powdery mildew fungus on petunia in the USA: A potential threat to ornamental and vegetable solanaceous crops. Plant Dis. 92:818-825.

This is the first North American report of Oidium longipes, an anamorphic powdery mildew species described recently in Europe. It was found on vegetatively propagated petunia grown in a commercial greenhouse in New Jersey, USA, where it caused a rapidly spreading disease. The pathogen might have originated offshore and may have already been distributed in the United States through horticultural trade. During field surveys in Europe, it was found on petunia in Hungary and Austria as well; this is the first report of $O$. longipes from these two countries. A detailed light microscopy study of American and European specimens of $O$. longipes, including freshly collected samples and authentic herbarium specimens, revealed that its conidiophore morphology is more variable than illustrated in the original species description or in subsequent works. Microcycle conidiation, a process not yet known to occur in powdery mildews, was repeatedly observed in $O$. longipes. The rDNA internal transcribed spacer (ITS) sequences were identical in colonies containing different conidiophore types as well as in a total of five specimens collected from petunia in the United States, Austria, Hungary, Germany, and Switzerland. A phylogenetic analysis of the ITS sequences revealed that the closest known relative of $O$. longipes is $O$. lycopersici, known to infect tomato only in Australia. Cross-inoculation tests showed that $O$. longipes from petunia heavily infected tobacco cv. Xanthi, while the tomato and eggplant cultivars tested were moderately susceptible to this pathogen. These results indicate that its spread represents a potential danger to a number of solanaceous crops. Our ad hoc field surveys conducted in 2006 and 2007 did not detect it outside New Jersey in the United States; all the other powdery mildew-infected petunias, collected in New York and Indiana, were infected by Podosphaera xanthii. In Europe, most of the powdery mildew-infected petunias examined in this study were infected by P. xanthii or Golovinomyces orontii. Our multiple inoculation tests revealed that the same petunia plants and even the same leaves can be infected concomitantly by $O$. longipes, $O$. neolycopersici, G. orontii, and $P$. xanthii. Thus, it is at present unclear to what extent $O$. longipes contributes to the powdery mildew epidemics that develop year after year on solanaceous plants in many parts of the world.
\end{abstract}

Solanaceous plants are attacked by many powdery mildew fungi worldwide. For example, Leveillula taurica and Golovinomyces orontii (formerly known as Erysiphe cichoracearum or E. orontii) are both known as pathogens of many wild and cultivated species of the Solanaceae, including important food crops such as

Corresponding author: L. Kiss

E-mail: LKISS@NKI.HU

* The $e$-Xtra logo stands for "electronic extra" and indicates that Figures 1 and 4 appear in color in the online edition.

Accepted for publication 2 January 2008.

doi:10.1094/PDIS-92-5-0818

(C) 2008 The American Phytopathological Society land (1,2), and Argentina (18). In addition, there are several other powdery mildew species that infect various wild solanaceous plants in different parts of the world $(3,4)$.

In 2006, during our annual field surveys for plant diseases of various vegetable and ornamental crops, unusual and rapidly spreading powdery mildew infections were observed on a vegetatively propagated cultivar of petunia in a commercial greenhouse in Pompton Plains, NJ, USA. Based on morphological characteristics, the pathogen was tentatively identified as $O$. longipes, a powdery mildew species not yet known to occur in North America. Identification of anamorphic species of the Erysiphales using light microscopy is, however, often less reliable than identification of the teleomorph stage $(8,32)$. Molecular tools, in particular the analysis of the internal transcribed spacer (ITS) sequences of the nuclear ribosomal DNA (rDNA), were useful in the precise identification of a large number of powdery mildew anamorphs $(6,7,11,12,14,22,27$, $33,34)$. Thus, we supplemented our work with ITS sequence analyses to confirm the identity of $O$. longipes in the United States and also to investigate its phylogenetic relationship with some other powdery mildew pathogens. In particular, we were interested in the relationship between the anamorph found on petunia in New Jersey and $O$. lycopersici, infecting tomato in Australia, because previous studies indicated a close phylogenetic relationship between a European $O$. longipes specimen and $O$. lycopersici $(11,21)$.

As $O$. longipes is a little-known powdery mildew species even in Europe, where it was originally described from the Netherlands in 1989 (25), we conducted field surveys to detect this pathogen in European countries, as well. Also, we conducted cross-inoculation experiments to learn more about the host range of this fungus and to determine whether it can cause disease on plant species other than those on which it has been found.

Overall, the objectives of this study were to (i) determine whether the powdery mildew anamorph infecting a commercial 
petunia crop in New Jersey is a new plant pathogen in the United States, (ii) investigate its phylogenetic relationship with closely related powdery mildew fungi, (iii) look for the same pathogen in Europe, and (iv) determine whether it can infect solanaceous crops other than its original hosts.

\section{MATERIALS AND METHODS}

Fungal materials. Powdery mildewinfected petunia leaves were collected from five sample locations in the United States and eight sample locations in Europe (Table 1). Currently, only three herbarium specimens of $O$. longipes infecting petunia (HAL608, HAL1678, and HAL1688) are known worldwide; these were included in this study, together with three Australian herbarium specimens of $O$. lycopersici. The designations and sources of powdery mildew samples included in this study are shown in Table 1.

To isolate $O$. longipes from the field, and to maintain the living mycelium of the fungus for cross-inoculation tests, healthy potted $P . \times$ hybrida Wave Blue plants, grown from seeds in isolation in controlled environment climate chambers (CECCs), were infected with a few conidia taken with a sterile brush from single young mildew colonies from petunia leaves collected from the field. The inoculated plants were then kept in isolation under transparent plastic covers in CECCs, and the pathogen was transferred monthly to healthy potted petunia plants grown from seeds in isolation. A $21^{\circ} \mathrm{C}$ constant temperature, $85 \%$ relative humidity $(\mathrm{RH})$, and 16-h artificial daily illumination was provided in all CECCs. Two O. longipes isolates, designated OL-HU1 and OL-AT1 (Table 1), were obtained in this way from mildew-infected petunia plants collected in Hungary and Austria, respectively, approximately $300 \mathrm{~km}$ away from each other.

Light microscopy. Hyphae, conidiophores, and conidia of fresh materials were stripped off the leaf surfaces with clear adhesive tape or with a razor blade together with the leaf epidermis, mounted on a microscope slide, and examined in water or in cotton blue in lactophenol, using light microscopy with or without differential interference contrast (DIC) optics. Herbarium materials were rehydrated before examination as described by Shin and $\mathrm{La}$ (28). After boiling, the rehydrated mycelium was scraped off the leaf and mounted either in lactic acid or in cotton blue in lactic acid for light microscopy. The following morphological patterns were examined during the study of both fresh and herbarium specimens: size and shape of conidia, presence or absence of fibrosin bodies in fresh materials, nature of conidiogenesis, characteristics of the conidiophore (e.g., size and shape of the foot cell and other cells of the conidiophores and position of the basal septum), shape and position of hyphal appressoria, position of germ tubes of conidia, when found, and shape of appressoria on germ tubes of conidia.

DNA extraction and polymerase chain reaction (PCR) amplification of the rDNA ITS region. DNA was obtained from both fresh powdery mildew conidia, collected with sterile brushes from mildew-infected leaves, and dried mycelia, scraped off of herbarium specimens using

Table 1. Designation, host plants, date and place of collection, herbariuma, and GenBank accession numbers of the powdery mildew specimens included in this study

\begin{tabular}{|c|c|c|c|c|}
\hline Designation & Host plant & Date and place of collection & $\begin{array}{l}\text { Herbarium accession no. } \\
\text { of new specimens }\end{array}$ & $\begin{array}{l}\text { GenBank accession no. } \\
\text { of rDNA ITS sequences }\end{array}$ \\
\hline \multicolumn{5}{|c|}{ Oidium longipes field samples } \\
\hline OL-US1 & $\begin{array}{l}\text { Petunia } \times \text { hybrida } \\
\text { Surfinia Violet }\end{array}$ & May 2006, Pompton Plains, NJ, USA & HAL 2071F, BPI 878251 & EU327321 \\
\hline OL-HU1 & P. $\times$ hybrida Wave Blue & October 2006, Martonvásár, Hungary & HAL 2072F, BPI 878253 & EU327322 \\
\hline OL-AT1 & $P . \times$ grandiflora & October 2006, Aspang, Hungary & HAL 2070F, BPI 878252 & EU327323 \\
\hline \multicolumn{5}{|c|}{ Oidium longipes herbarium specimens } \\
\hline HAL 608 & P. $\times$ hybrida & October 1996, Morges, Switzerland & & EU327324 \\
\hline HAL 1678 & P. $\times$ hybrida Surfinia & October 1994, Hessen, Germany & & EU327325 \\
\hline HAL 1688 & P. $\times$ hybrida Surfinia & May 1995, Hessen, Germany & & \\
\hline \multicolumn{5}{|c|}{ Podosphaera xanthii field samples } \\
\hline PX-US1 & P. $\times$ hybrida & September 2006, Indianapolis, IN, USA & & \\
\hline PX-US2 & P. $\times$ hybrida & October 2006, Mattituck, NY, USA & & \\
\hline PX-US3 & P. $\times$ hybrida & October 2006, Jamesport, NY, USA & BPI 878254 & EU327326 \\
\hline PX-US4 & P. $\times$ hybrida & October 2006, Jamesport, NY, USA & & \\
\hline PX-US5 & $\begin{array}{l}\text { P. } \times \text { hybrida } \\
\text { Whispers Rose Vein }\end{array}$ & October 2006, Riverhead, NY, USA & & \\
\hline PX-US6 & $\begin{array}{l}\text { P. } \times \text { hybrida } \\
\text { Jamboree Light Blue }\end{array}$ & August 2007, Riverhead, NY, USA & & \\
\hline PX-US7 & $\begin{array}{l}\text { P. } \times \text { hybrida } \\
\text { Jamboree Hot Pink }\end{array}$ & August 2007, Riverhead, NY, USA & & \\
\hline PX-US8 & $\begin{array}{l}\text { P. } \times \text { hybrida } \\
\text { Cascadias Bicolor Fantasy }\end{array}$ & August 2007, Riverhead, NY, USA & & \\
\hline PX-US9 & P. $\times$ hybrida Littletunia Rose & August 2007, Riverhead, NY, USA & & \\
\hline PX-US10 & P. $\times$ hybrida Whispers Scarlet & August 2007, Riverhead, NY, USA & & \\
\hline PX-HU1 & P. $\times$ hybrida & October 2006, Bicsérd, Hungary & & \\
\hline PX-HU2 & P. $\times$ hybrida & October 2006, Törökszentmiklós, Hungary & & EU327327 \\
\hline \multicolumn{5}{|c|}{ Golovinomyces orontii field samples } \\
\hline GO-HU1 & P. $\times$ hybrida & August 2006, Martonvásár, Hungary & BPI 878255 & EU327328 \\
\hline GO-HU2 & P. $\times$ hybrida & August 2006, Újfehértó, Hungary & BPI 878256 & \\
\hline GO-HU3 & P. $\times$ hybrida & August 2006, Isaszeg, Hungary & BPI 878257 & \\
\hline GO-HU4 & P. $\times$ hybrida & August 2006, Törökszentmiklós, Hungary & & \\
\hline GO-HU5 & P. $\times$ hybrida & October 2006, Ráckeresztúr, Hungary & & \\
\hline GO-SE1 & P. $\times$ hybrida & September 2006, Palics, Serbia & & EU327329 \\
\hline \multicolumn{5}{|c|}{ Oidium lycopersici herbarium specimens } \\
\hline DAR 35763 & Solanum lycopersicum & 1980, Victoria, Australia & & EU327330 \\
\hline DAR 70008 & S. lycopersicum & 1994, Tasmania, Australia & & EU327331 \\
\hline DAR 71625 & S. lycopersicum & 1996, South Australia, Australia & & EU327332 \\
\hline
\end{tabular}

${ }^{\mathrm{a}}$ BPI = U.S. National Fungus Collections, Beltsville, MD, USA; DAR = Plant Pathology Herbarium, Orange Agricultural Institute, Australia; HAL = Herbarium of Martin Luther University, Halle, Germany.

b If determined. ITS = internal transcribed spacer. 
a razor blade. When fresh conidia were used, they were washed into Eppendorf tubes containing $1 \mathrm{ml}$ of sterile water, and the conidial suspensions were centrifuged for $5 \mathrm{~min}$ at 13,000 rpm, and the supernatant was discarded. The pellets were frozen, freeze-dried, and stored at $-18^{\circ} \mathrm{C}$ until use. Whole-cell DNA was extracted from the freeze-dried pellets, and from dried mycelia collected from herbarium specimens, using a Qiagen DNeasy Plant Mini Kit (Qiagen $\mathrm{GmbH}$, Hilden, Germany). The rDNA ITS region was amplified using the ITS1F/ITS4 fungal-specific primer pair (16) as described in Szentiványi et al. (31). PCR products were purified using a PCR-M Clean Up System purification kit (Viogene) and sequenced using a BigDye Terminator v3.1 Cycle Sequencing Kit (Applied Biosystems, Foster City, CA) according to the manufacturers' instructions. Both strands were sequenced with the primers used for PCR amplification of the ITS region. Electrophoresis was carried out on an ABI PRISM 3100 Genetic Analyzer.

Phylogenetic analyses. Sequences were compiled from electrophoregrams using Pregap4 and Gap4 (29). Multiple alignments of homologous ITS sequences obtained from GenBank were made using Multalin (9). The alignments were checked and manually edited with ProSeq 2.9 (13). For inferring phylogenies, parsimony analysis was carried out using the PAUP* $4.0 \mathrm{~b} 10$ program package (30). Gaps in the alignment were treated as the fifth character, and all characters had equal weight. The other parameters were the default set of the PAUP* with "Multrees" on. The statistical supports of the branches of the inferred trees were tested using bootstrap analysis with 1,000 replicates. Phylogenetic trees were visualized and edited by Tree Explorer of the MEGA 3.1 program (23). Supporting data are available on the following web page: http://ludens.elte.hu/ qgmkovacs/.

Cross-inoculation tests. Tomato plants cv. Kecskeméti Jubileum, tobacco plants cv. Xanthi, petunia plants Wave Blue, and eggplant cv. Kecskeméti Lila were grown from seeds in pots in isolation in CECCs until four to eight fully expanded leaves developed. At this stage, three pots for each plant species were placed in another CECC, and the plants were inoculated with O. longipes isolate OL-HU1 by touching their leaves to powdery mildew colonies growing on infected petunia plants. Three other pots for each plant species (tomato, tobacco, eggplant, and petunia) were simply placed close to a potted petunia plant infected with isolate OL-HU1 in the same CECC. The same tests were carried out with isolate OL-AT1 in other CECCs. The temperature, $\mathrm{RH}$, and illumination parameters provided in all CECCs were identical with those described above. Three additional pots for each plant species, without inoculations with powdery mildew, were kept in another CECC with the same parameters to serve as negative controls. The tests with isolates OL-HU1 and OL-AT1 were repeated twice. The same tests were set up in two greenhouse compartments in November 2006. In these facilities, plants inoculated with isolates OL-HU1 and OLAT1 were kept under two different transparent plastic covers. Noninoculated control plants were kept under separate covers. The natural daily illumination was supplemented with $4 \mathrm{~h}$ of artificial light per day in the greenhouse compartments, and the temperature was kept between 18 and $24^{\circ} \mathrm{C}$ and $\mathrm{RH}$ between 70 and $90 \%$ in both compartments. All test plants were visually examined for the presence of powdery mildew colonies 1,2 , and 3 weeks after inoculation. If found, the morphological patterns of the pathogens were verified under the light microscope to exclude the possibility of an alien powdery mildew infection caused by a pathogen other than O. longipes.

Multiple inoculation tests. Two experiments were carried out to determine whether the same petunia plants/leaves are susceptible to more than one powdery mildew species. For this purpose, petunia plants with four to eight fully expanded leaves, grown from seeds in CECCs as described above, were inoculated with the following four powdery mildew isolates: $O$. longipes isolate OL-HU1, O. neolycopersici isolate BP-P5, G. orontii isolate BP-TOB, and P. xanthii isolate BP-CUC. The O. neolycopersici, G. orontii, and $P$. xanthii isolates were maintained in the greenhouse on tomato, tobacco, and cucumber, respectively. Inoculations of healthy petunia plants were done with a few conidia taken with sterile brushes from single young mildew colonies grown on potted petunia, tomato, tobacco, and $\mathrm{cu}-$ cumber plants used to maintain the four powdery mildew isolates in the greenhouse. Each petunia plant was inoculated with a pair of the four powdery mildew isolates used in these tests (e.g., $O$. longipes OL-HU1/O. neolycopersici BP$\mathrm{P5})$ : two leaves were inoculated with one of the isolates, two with the other isolate, and two with both, by touching the brushes with the inocula only once to a place on the leaf marked with a pen. All these inoculations were done in isolated conditions to prevent the spread of inocula to unwanted places. Five plants were used for each isolate pair, and the experiment was carried out two times. The inoculated plants were kept under transparent plastic covers in CECCs for 4 to 8 days only, to prevent the newly produced powdery mildew colonies from merging. The young colonies were removed from the leaves with pieces of adhesive tape and examined under a light microscope. The four powdery mildew species were easily distinguished from each other even in these early stages of their colony formation. Fibrosin bodies in conidia were diagnostic for $P$. xanthii; conidia produced singly were diagnostic for $O$. neolycopersici; smooth conidiophores with basal septa sometimes displaced from the point of branching and sometimes containing an exceptionally long cell were diagnostic for $O$. longipes; and thicker conidiophores without very long cells and producing conidia in chains, but without fibrosin bodies, were diagnostic for $G$. orontii. All inoculated petunia plants were destroyed after use to protect other plants from unwanted infections.

\section{RESULTS}

First record of $O$. longipes in the United States, Hungary, and Austria. A light microscopy study of the powdery mildew anamorph found on petunia in a commercial greenhouse in Pompton Plains, NJ, USA, and designated OL-US1, showed that a number of its conidiophores were extremely long, up to $277 \mu \mathrm{m}$, mostly because the second or third cell of the conidiophore was unusually long for an Oidium anamorph (Fig. 1A and B), measuring 102-187 × 7-9 $\mu \mathrm{m}$. Such conidiophores are typical of $O$. longipes according to the original description of the species (25), and also according to Braun $(4,5)$ and Bolay $(1,2)$, and cannot be confused with those of any other powdery mildew anamorphs known to infect petunia. However, the morphological characteristics of the conidiophores were more variable than suggested by these earlier works $(1,2,4,5,25)$. Thus, a comprehensive light microscopy analysis was carried out to compare the morphology of isolate OL-US1 with that of the three authentic $O$. longipes herbarium specimens (HAL 608, HAL 1678, and HAL 1688) and also with that of two European isolates, OL-HU1 and OLAT1, collected from petunia in a Hungarian and an Austrian locality, respectively, during our European field surveys in 2006 (Table 1). Isolates OL-HU1 and OL-AT1 were tentatively identified as $O$. longipes based on the presence of very long second or third cells in their conidiophores. These two isolates were maintained on potted petunias in CECCs and were used in subsequent cross-inoculation tests, as well.

In addition to the morphological patterns, the rDNA ITS sequences were also determined in the three powdery mildew isolates (OL-US1, OL-HU1, and OL-AT1), tentatively identified as $O$. longipes, and also in two authentic $O$. longipes herbarium specimens (HAL608 and HAL1678). All five ITS sequences obtained were identical to the ITS sequence of $O$. longipes collected from eggplant in Switzerland (GenBank accession number: AF250777), the only ITS sequence for $O$. longipes available in DNA databases at this time.

Both the morphological characteristics and the ITS sequences confirmed that iso- 
lates OL-US1, OL-HU1, and OL-AT1 collected from petunia in the United States, Hungary, and Austria, respectively, represent $O$. longipes. To our knowledge, this is the first report of this fungus from North America, Hungary, and Austria. Specimens of isolates OL-US1, OL-HU1, and OL-AT1 were deposited at the Herbarium of Martin Luther University (HAL), Halle, Germany, and also at the U.S. National Fungus Collections (BPI), Beltsville, MD, USA (Table 1).

Morphological characteristics of $\boldsymbol{O}$. longipes conidiophores. In addition to conidiophores containing an exceptionally long second (Fig. 1A and C) or third (Fig. $1 \mathrm{~B}$ and $\mathrm{D})$ cell, measuring up to $225 \times 10$ $\mu \mathrm{m}$ in some of the samples examined in this study, and designated by us as type 1 , other conidiophore types were also found in the powdery mildew mycelia covering petunia leaves, sometimes next to conidio- phores described as diagnostic for $O$. longipes. In some cases, different conidiophore types were produced on the same hypha on petunia leaves. Some of them, designated by us as type 2 , consisted of a moderately long foot-cell, measuring 45 $72 \times 7-9 \mu \mathrm{m}$, followed by two cells of approximately the same length, and then followed by one to three shorter cells, 18$24 \times 9-10 \mu \mathrm{m}$. This conidiophore type of O. longipes was mentioned by Braun (5) but by neither Noordeloos and Loerakker (25) nor Bolay $(1,2)$. We also found conidiophores in which only the foot-cell was moderately long, measuring 70-91 $\times$ 7-10 $\mu \mathrm{m}$ (Fig. 1E), and the foot-cell was followed by zero to three shorter sterile cells before the conidium initials, as illustrated by Bolay (2) for O. longipes. We designated this conidiophore variant as type 3. Thus, in types 2 and 3, an exceptionally long cell was not present. Another
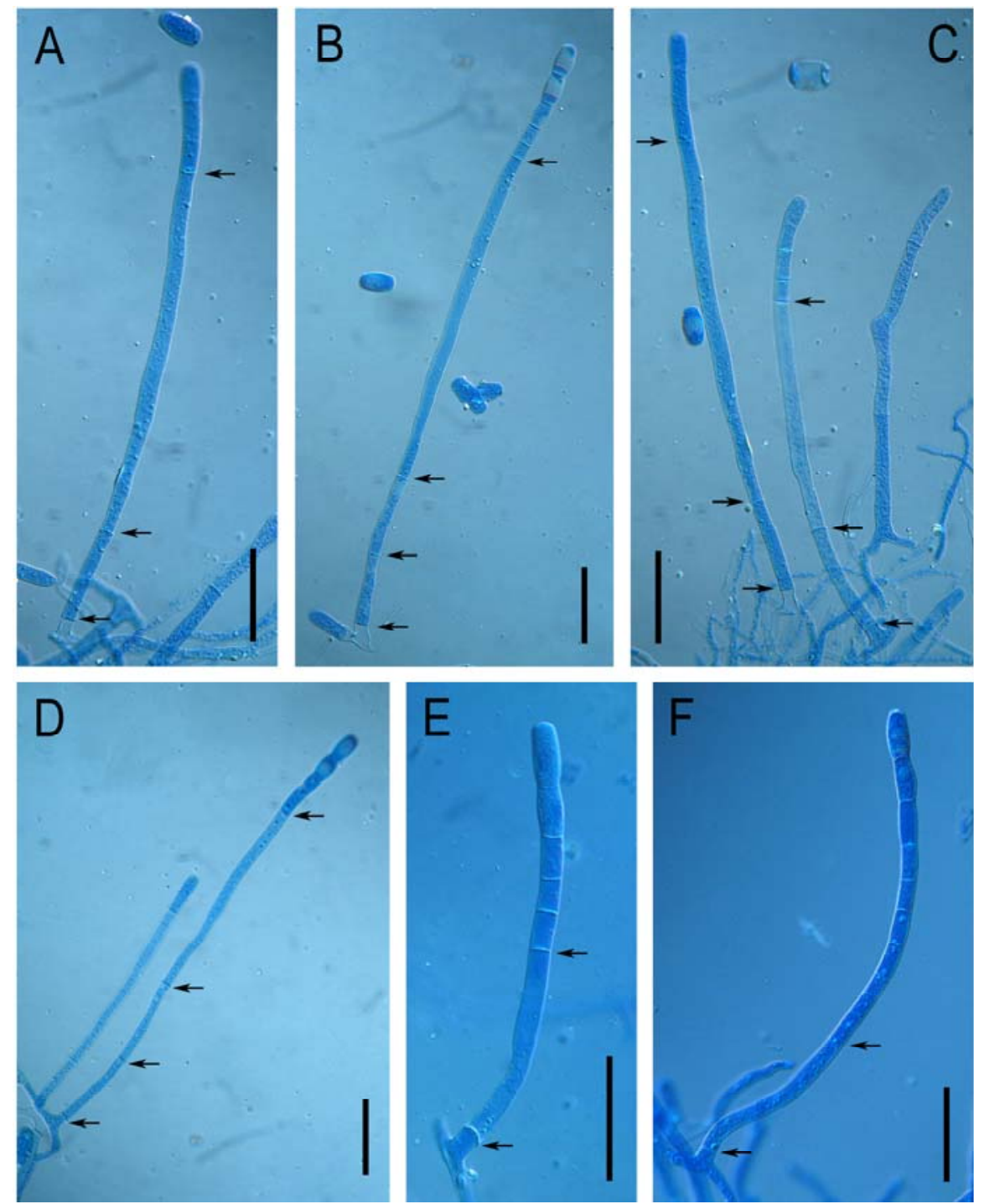

Fig. 1. Micrographs of conidiophores of Oidium longipes infecting petunia. Bars equal $50 \mu \mathrm{m}$. Arrows indicate septa. A, Conidiophore with an exceptionally long second cell. B, Conidiophore with an exceptionally long third cell. C, Three conidiophores, of which two mature ones possess exceptionally long second cells while the third (right hand side) is still immature. D, An immature conidiophore and a mature one with an exceptionally long third cell. E, Mature conidiophore without any exceptionally long cells. F, Conidiophore with a moderately long foot-cell followed by eight short sterile cells and conidium initials. conidiophore type, number 4 , observed in some of our samples, consisted of a long foot-cell, $81-122 \times 7-9 \mu \mathrm{m}$, followed by up to six to eight shorter sterile cells before the conidium initials started to develop (Fig. 1F). In another conidiophore type, number 5 , a short foot-cell, 48-67 × 7-9 $\mu \mathrm{m}$, was followed by three to five cells of approximately the same size, then by an exceptionally long cell, measuring 105$181 \times 8-10 \mu \mathrm{m}$, followed by one to two shorter cells and conidium initials. Thus, in type 5 conidiophores, it was the fourth, fifth, or sixth cell that was unusually long.

To ensure that all five conidiophore types observed in different field samples and/or on potted petunia plants used to maintain the pathogen in CECCs belonged to $O$. longipes, small, approximately 0.5 to $1 \mathrm{~cm}^{2}$ leaf pieces were cut out of the infected leaves after light microscopy revealed the presence of one or more "unusual" conidiophore types in that part of the powdery mildew mycelium. DNA was extracted from the mycelium, and the ITS sequence was determined in the fungus. This procedure was repeated four times with parts of mycelia that contained different conidiophore types suspected to belong to O. longipes. In all these samples, the ITS sequences were identical to those determined earlier in $O$. longipes, thus confirming that the conidiophore morphology is more variable in this species than illustrated in the original species description (25) or in subsequent works $(1,2,4,5)$.

The mycelia of $O$. longipes collected from petunia in the United States and Europe contained various amounts of different conidiophore types. Some of them,

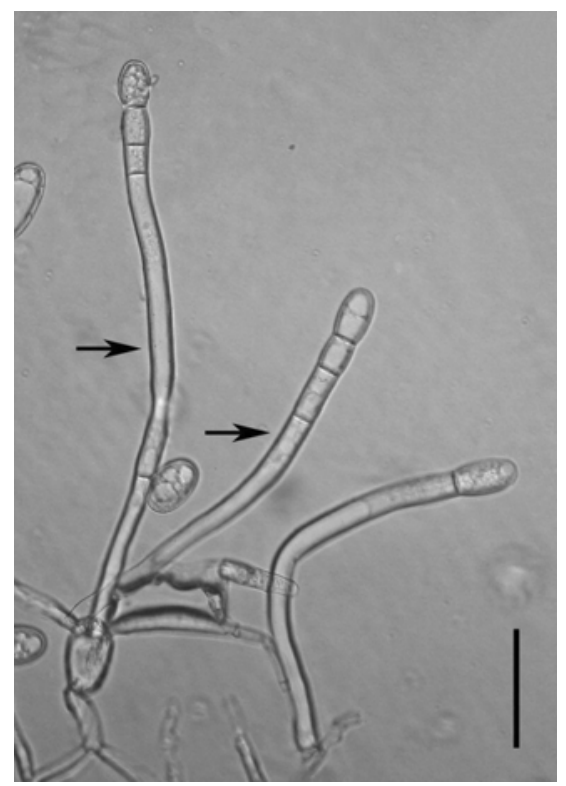

Fig. 2. Microcycle conidiation in Oidium longipes on a petunia leaf: during germination, a conidium developed a conidiophore (arrow, left) and three long germ tubes, of which one produced another conidiophore (arrow, right) immediately after it had emerged from the conidium. Bar equals $50 \mu \mathrm{m}$. 
especially the U.S. sample, contained many young conidiophores in which the growth of the cells and the development of the septa were still in progress. A number of such young, not exceptionally long conidiophores had already started to produce conidia, although most probably their growth had not finished yet (Fig. 2). Other young conidiophores of approximately the same size terminated in rounded apices because conidiogenesis had not yet begun (Fig. 1C).

All the mature conidiophore types of $O$. longipes had a number of characteristics in common. In all of them, width increased from base to top, and sometimes enlarged considerably at a particular point of the foot-cell (Fig. 1E) or a subsequent cell (Fig. 1A to D). Basal septa of the conidiophores were usually displaced by 5 to 37 $\mu \mathrm{m}$ from the point of branching (Fig. 1A to F). The shorter cells that usually followed the longer ones were hardly distinguishable from the youngest conidium initial. The number of conidium initials and mature conidia varied between three and five per conidiophore. As recently demonstrated, air movements influence the number of conidia that remain attached to a powdery mildew conidiophore (26); thus the number of conidia found on conidiophores strongly depends on abiotic factors.
Mature, detached conidia measured 23-32 $\times 11-17 \mu \mathrm{m}$. During germination, these produced mostly one, or occasionally two or three germ tubes at their ends. Germ tubes ended in rounded apices, without producing lobed appressoria. Curiously, some of these germ tubes elongated on the leaf surfaces and developed directly into young conidiophores that started to produce conidia (Fig. 2). This process, called microcycle conidiation (17), and observed in less than 2 to $5 \%$ of the germinated conidia in various samples, has not yet been described for any powdery mildew species. Hyphal appressoria were always simple, nipple-shaped, never lobed, and

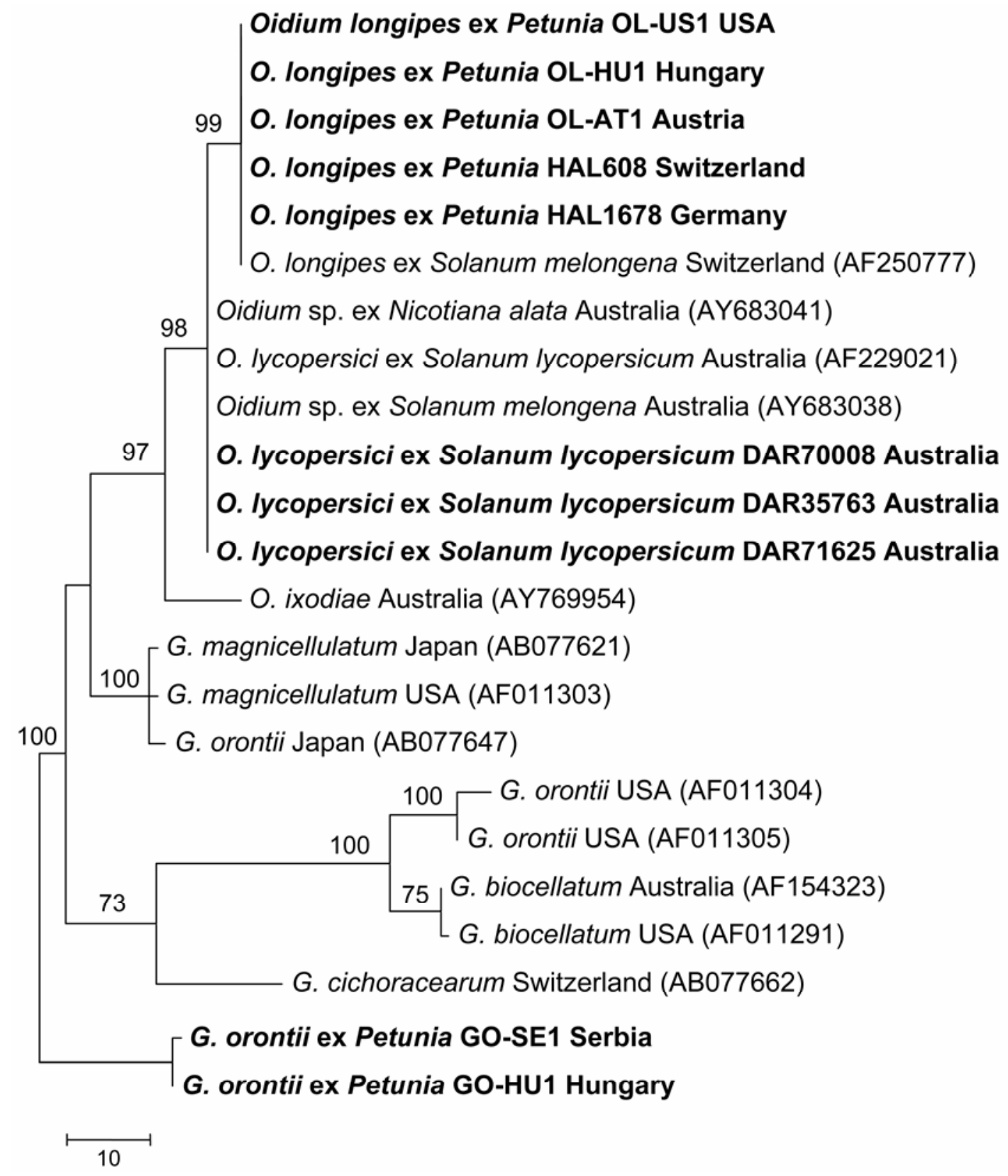

Fig. 3. One of the two most parsimonious trees inferred from rDNA internal transcribed spacer (ITS) sequences of 23 powdery mildew specimens with PAUP* 4.0b10 program package (30). Ten of the 23 ITS sequences analyzed were determined in this study. These are shown in bold. GenBank accession numbers of the sequences from earlier studies are shown in parentheses. ITS sequences of Golovinomyces orontii Go-SE1 and G. orontii Go-HU1 served as an outgroup. Gaps in the 524-character-long alignment (with 72 parsimony informative characters) were treated as fifth characters, and all characters had equal weight. Other parameters followed the basic set of the PAUP* with "Multrees" on. Bootstrap values were obtained from 1,000 replicates and are indicated as percentages. Scores below $75 \%$ are not shown. Bar $=10$ changes. 
were found singly or in sequence along the hyphae.

Phylogenetic analysis of ITS sequences. A 524-character-long alignment of the ITS sequences of 23 powdery mildew specimens, including 10 sequences determined in this study, was used in the phylogenetic analyses. Two equally parsimonious trees were obtained that differed only in the branching order within the $G$. magnicellatum group. One of these trees is shown in Figure 3. The five $O$. longipes specimens with identical ITS sequences formed a subgroup that was separated unambiguously, with $99 \%$ bootstrap support, from the $O$. lycopersici subgroup consisting of four specimens of $O$. lycopersici collected from tomato and two other Oidium anamorphs collected from eggplant and Nicotiana alata, respectively, in Australia. Three out of these six Australian specimens were sequenced in this study (Table 1), while the other three ITS sequences originated from GenBank. All six ITS sequences of the $O$. lycopersici subgroup were identical and differed from the five $O$. longipes sequences only in the length of a poly-T motif at the $3^{\prime}$ end of the ITS 2 region. This motif consisted of 14 ' $\mathrm{T}$ ' characters in the $O$. longipes sequences and 10 ' $\mathrm{T}$ ' characters in the sequences of the $O$. lycopersici subgroup. The $O$. longipes and the $O$. lycopersici subgroups formed a well-supported clade that grouped together with $O$. ixodiae, a newly described Australian species infecting Ixodia achilleoides (10) (Fig. 3).

Other powdery mildew species identified on petunia. During our field surveys, $G$. orontii and/or $P$. xanthii were also found on petunia in the United States and Hungary, in addition to $O$. longipes, sometimes in the same area (Table 1). For example, in Martonvásár, Hungary, different leaves of the same petunias planted as outdoor ornamentals were infected with $G$. orontii in August 2006, and with $O$. longipes in October 2006. However, the powdery mildew mycelia found on infected petunia leaves collected from a particular location on one sample date always contained conidiophores of only a single species. Thus, we found no evidence of multiple infections of the same leaves caused concomitantly by more than one species in the field.

The ITS sequences determined in some of the $G$. orontii and $P$. xanthii specimens collected from petunia in this study, and deposited in GenBank (Table 1), were 99\% similar to published ITS sequences of these fungi. Herbarium specimens of most of the specimens examined in this study were deposited at HAL and BPI (Table 1).

Inoculations of tobacco, eggplant, and tomato with $\boldsymbol{O}$. longipes. All the artificial inoculations of tobacco cv. Xanthi, eggplant cv. Kecskeméti Lila, and tomato cv. Kecskeméti Jubileum with $O$. longipes isolates OL-HU1 and OL-AT1 resulted in rapidly extending and extensively sporulating powdery mildew colonies on tobacco (Fig. 4), and weak mycelial growth with sparse sporulation, followed by necrosis, on eggplant and tomato. Both inoculation methods, i.e., touching infected leaves to healthy ones and placing infected potted plants in the vicinity of the test plants in CECCs, led to the same results. These tests indicated that $O$. longipes from petunia can infect solanaceous plants other than its original host.

Multiple powdery mildew infections of petunia. To test experimentally whether the same petunia plants could be infected concomitantly by more than one powdery mildew species, potted plants grown from seeds in isolation in CECCs were infected with pairs of the following fungi: $O$. longipes isolate OL-HU1, O. neolycopersici isolate BP-P5, G. orontii isolate BPTOB, and P. xanthii isolate BP-CUC. Two leaves of each plant were inoculated with one powdery mildew species, two with another species, while two other leaves were inoculated with both of them by placing the inoculum onto a single marked place on each leaf. In all these pairing experiments, mycelia of all four powdery mildew species tested started to develop on all of the inoculated leaves. This indicated that the same petunia plants and even the same leaves could be infected by more than one powdery mildew species at the same time.

\section{DISCUSSION}

This study revealed that $O$. longipes occurs in the United States on petunia and also in parts of Europe, notably Hungary and Austria, where its presence has not been reported previously. Braun (4) has already suggested that this species might be more widespread in Europe than reported. In both North America and Europe, it could be even more common than indicated by the present work. We assume there are two main reasons why reports of this species are so limited. First, petunia and eggplant, its known natural hosts, are economically less important than the major solanaceous crops, tomato, potato, and tobacco. More importantly, both petunia and eggplant are regularly infected with other powdery mildews, notably $G$. orontii and $P$. xanthii, which were recovered in this study in the United States and/or Europe from petunia (Table 1), and a superficial check of the infections could easily result in a misidentification of the pathogen. These two better-known species produce visual symptoms very similar to those produced by $O$. longipes. In addition, the morphology of $G$. orontii conidiophores is somewhat similar to that of $O$. longipes conidiophores, especially when colonies are young and the exceptionally long conidiophores diagnostic for $O$. longipes have not yet been produced on the infected plants. Clearly, a more extensive search would be needed to reveal the presence of $O$. longipes on eggplant, petunia, tobacco, tomato, or solanaceous weeds or wild plant species in additional places in North America. This would be particularly important because it is at present unclear whether $O$. longipes has emerged in North America only recently, being present only on petunias and in the northeastern United States, or if it is an ignored but widespread fungus infecting several members of the Solanaceae all over the continent. Our ad hoc surveys did not detect it on petunias outside New Jersey; all the other powdery

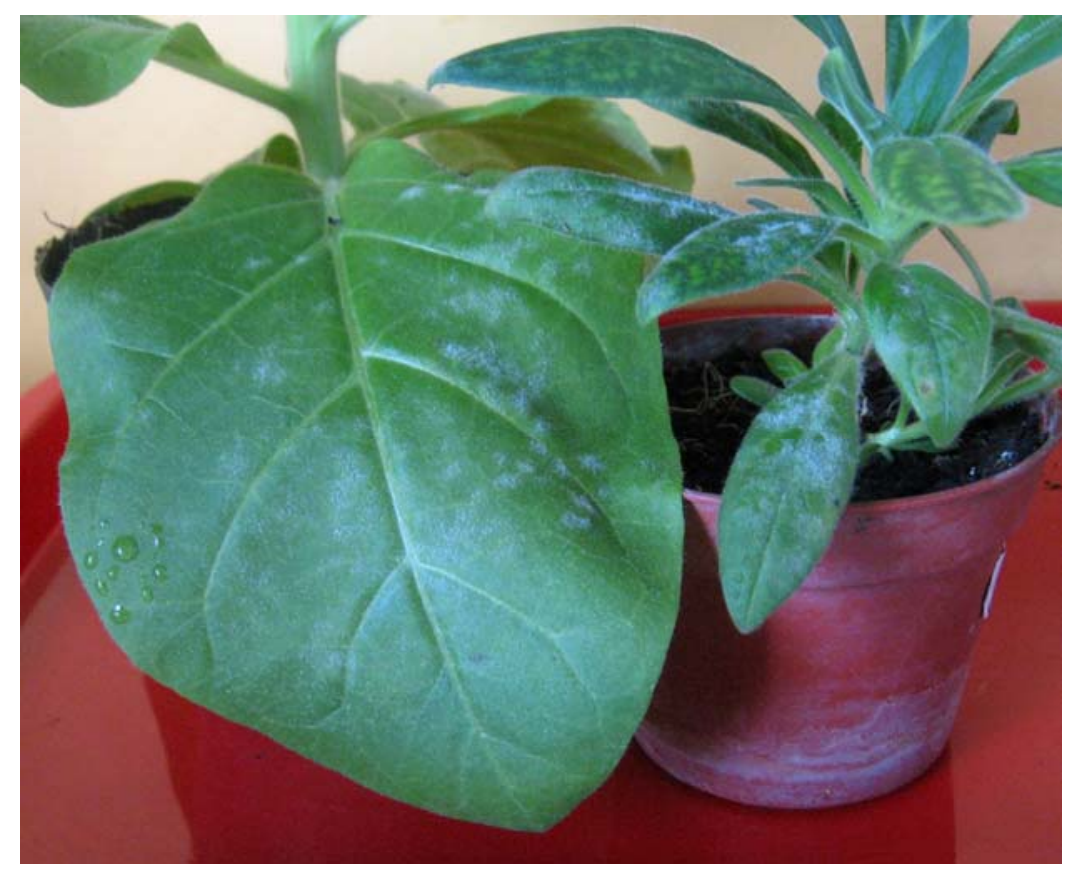

Fig. 4. Tobacco cv. Xanthi was readily infected in a cross-inoculation test with Oidium longipes maintained on petunia Wave Blue. 
mildew infections examined on petunias in the United States, in Indiana and New York, were caused by P. xanthii (Table 1), a well-known pathogen of many plant species worldwide. The vegetatively propagated petunia plants infected with O. longipes in Pompton Plains, NJ, were destroyed, but it is possible that other greenhouse businesses might have unknowingly distributed this pathogen through regular marketing channels, not realizing it was a species not known to occur in North America. Vegetative propagation of petunia cultivars is conducted in Central and South America, where the presence of $O$. longipes has recently been documented (18), and cuttings are exported to the United States and Europe. O. longipes detected on petunia Surfinia Violet in New Jersey might have originated offshore, and could have been widely distributed in North America during spring 2006 or earlier through horticultural trade.

Our cross-inoculation experiments were not extensive enough to determine the exact host range of $O$. longipes. However, these tests showed that $O$. longipes from petunia heavily infected tobacco cv. Xanthi (Fig. 4), and an eggplant and a tomato cultivar tested were also moderately susceptible to this fungus. This indicates that $O$. longipes might represent a danger to other important solanaceous crops, in addition to petunia. Again, it would be essential to determine whether this pathogen is a recently emerged one in both Europe and North America because powdery mildew epidemics develop regularly on solanaceous crops, including tomato, eggplant, tobacco, and petunia, and it is unclear whether $O$. longipes has simply been overlooked as one of the major causal agents of these widespread infections in the past. Our multiple inoculation tests indicated that pairs of at least four different powdery mildew species, O. longipes, G. orontii, O. neolycopersici, and $P$. xanthii, could infect petunia plants at the same time. Infections caused by $G$. orontii and $P$. xanthii on the same petunia plants, but at different times, were observed in the field in Törökszentmiklós, Hungary (Table 1). Thus, it is possible that more than one pathogen may contribute to the powdery mildew epidemics that develop year after year on solanaceous plants in many parts of the world.

Tomato plants cv. Kecskeméti Jubileum were moderately susceptible to $O$. longipes in our tests. In contrast, Noordeloos and Loerakker (25) were unable to infect tomato with this fungus. Based on ITS sequence analyses (Fig. 3), the closest relative of $O$. longipes is $O$. lycopersici infecting tomato, a species only known to occur in Australia. The only difference in the ITS sequences of $O$. longipes and $O$. lycopersici is the length of a poly-T motif in the ITS 2 region, as pointed out by Cun- nington et al. (11) based on one sequence for each of these two taxa. In this study, we determined the ITS sequences in five other specimens of $O$. longipes, and in three Australian herbarium specimens of $O$. lycopersici. All the newly obtained sequences were identical to those determined previously in these two taxa, including the length of the poly-T motif. However, in spite of the similarities in ITS sequences, $O$. longipes and $O$. lycopersici clearly represent two distinct, but closely related species, especially because their host range is different and because, in addition, there are obvious differences in the morphology of their conidiophores as discussed by Kiss et al. (21). In $O$. ixodiae, the closest relative of $O$. longipes and $O$. lycopersici according to our analysis (Fig. 3 ), exceptionally long cells in the conidiophores and a displacement of the basal septa are also present, similar to $O$. longipes and $O$. lycopersici (10). The presence of a long cell in the conidiophore is characteristic to only a few powdery mildew species, such as $G$. depressus infecting asteraceous hosts (e.g., Arctium, Centaurea, and Onopordum spp.) (4) and O. pseudolongipes infecting Exacum (15). However, Cunnington et al. (10) showed that $G$. depressus is not closely related to $O$. longipes, $O$. ixodiae, and $O$. lycopersici based on an analysis of the ITS sequences.

Microcycle conidiation, a process defined as the germination of spores by the direct formation of conidia, without the intervention of mycelial growth (17), is known to occur in several fungal genera, such as Aspergillus, Penicillium, and $\mathrm{Neu}$ rospora. However, to our knowledge, it has not been reported in any powdery mildew species to date, even though germination patterns are important characteristics in the identification of powdery mildews and have been reported in comprehensive monographs $(3,4)$, as well as in many other works, for most species of the Erysiphales. We observed this process in a number of O. longipes samples (Fig. 2), thus it seems to be a rather common phenomenon in this little-known fungus. However, only a few conidia produced conidiophores immediately after germination, so further studies are needed to determine the significance of this process in the life cycle of $O$. longipes. Also, further studies are needed to determine whether microcycle conidiation occurs in other powdery mildew species as well.

\section{ACKNOWLEDGMENTS}

We thank Krisztina and Szilvia Szakolczai, Boróka Kiss, Zoltán Bognár, and Imre Holb for their help in collecting powdery mildew-infected petunias. The curator of HAL, Professor Uwe Braun, is also acknowledged for the loan of herbarium specimens. The support of a János Bolyai Research Fellowship and that of a postdoctoral research grant of the Hungarian Research Fund (OTKA, D048333), both awarded to GMK, are also gratefully acknowledged.
LITERATURE CITED

1. Bolay, A. 1998. Les oidiums de la tomate et de l'aubergine en Suisse. Rev. Suisse Vitic. Arboric. Hortic. 30:373-378.

2. Bolay, A. 2005. Les Oidiums de Suisse. Cryptogamica Helvetica 20:1-176.

3. Braun, U. 1987. A monograph of the Erysiphales (powdery mildews). Beih. Nova Hedwigia 89:1-700.

4. Braun, U. 1995. The Powdery Mildews (Erysiphales) of Europe. Gustav Fischer Verlag, Jena.

5. Braun, U. 1998. Neufunde Echter Mehltaupilze (Erysiphales) aus der BR Deutschland. Schlechtendalia 1:31-40.

6. Braun, U., Takamatsu, S., Heluta, V., Limkaisang, S., Divarangkoon, R., Cook, R. and Boyle, H. 2006. Phylogeny and taxonomy of powdery mildew fungi of Erysiphe sect. Uncinula on Carpinus species. Mycol. Progress 5:139-153.

7. Cook, R. T. A., Henricot, B., Henrici, A., and Beales, P. 2006. Morphological and phylogenetic comparisons amongst powdery mildews on Catalpa in the UK. Mycol. Res. 110:672 685.

8. Cook, R. T. A., Inman, A. J., and Billings, C. 1997. Identification and classification of powdery mildew anamorphs using light and scanning electron microscopy and host range data. Mycol. Res. 101:975-1002.

9. Corpet, F. 1988. Multiple sequence alignment with hierarchical clustering. Nucleic Acids Res. 16:10881-10890.

10. Cunnington, J. H., Beilharz, V. C., Pascoe, I. G., and Lawrie, A. C. 2005. Oidium ixodiae sp. nov. on Ixodia achilleoides in Australia. Australas. Plant Pathol. 34:91-94.

11. Cunnington, J. H., Lawrie, A. C., and Pascoe, I. G. 2005. Molecular identification of Golovinomyces (Ascomycota: Erysiphales) anamorphs on the Solanaceae in Australia. Australas. Plant Pathol. 34:51-55.

12. Cunnington, J. H., Takamatsu, S., Lawrie, A. C., and Pascoe, I. G. 2003. Molecular identification of anamorphic powdery mildews (Erysiphales). Australas. Plant Pathol. 32:421-428.

13. Filatov, D. A. 2002. ProSeq: A software for preparation and evolutionary analysis of DNA sequence data sets. Mol. Ecol. Notes 2:621624.

14. Francis, S. A., Roden, B. C., Adams, M. J., Weiland, J., and Asher, M. J. C. 2007 Comparison of ITS sequences from UK and North American sugar-beet powdery mildews and the designation of Erysiphe betae. Mycol. Res. 111:204-212.

15. Gabler, J., and Braun, U. 1995. Oidium pseudolongipes, a new powdery mildew on Exacum. Arnoldia 10:14-16.

16. Gardes, M., and Bruns, T. D. 1993. ITS primers with enhanced specificity for basidiomycetes-application to the identification of mycorrhizae and rusts. Mol. Ecol. 2:113-118.

17. Hanlin, R. T. 1994. Microcycle conidiation - A review. Mycoscience 35:113-123.

18. Havrylenko, M., and Takamatsu, S. 2005. Notes on Erysiphales (Ascomycetes) from Patagonia, Argentina. Mycoscience 46:32-38.

19. Hirata, T., Cunnington, J. H., Paksiri, U., Limkaisang, S., Shishkoff, N., Grigaliunaite, B., Sato, Y., and Takamatsu, S. 2000. Evolutionary analysis of subsection Magnicellulatae of Podosphaera section Sphaerotheca (Erysiphales) based on the rDNA internal transcribed spacer sequences with special reference to host plants. Can. J. Bot. 78:1521-1530.

20. Khodaparast, S. A., Takamatsu, S., and Hedjaroude, G. A. 2001. Phylogenetic structure of the genus Leveillula (Erysiphales: Erysiphaceae) inferred from the nucleotide sequences of the rDNA ITS region with special reference to the L. taurica species complex. Mycol. Res. 105:909-918. 
21. Kiss, L., Cook, R. T. A., Saenz, G. S., Cunnington, J. H., Takamatsu, S., Pascoe, I., Bardin, M., Nicot, P. C., Sato, Y., and Rossman, A. Y. 2001. Identification of two powdery mildew fungi, Oidium neolycopersici sp. nov. and $O$. lycopersici, infecting tomato in different parts of the world. Mycol. Res. 105:684-697.

22. Kiss, L., Takamatsu, S., and Cunnington, J. H. 2005. Molecular identification of Oidium neolycopersici as the casual agent of the recent tomato powdery mildew epidemics in North America. Plant Dis. 89:491-496.

23. Kumar, S., Tamura, K., and Nei, M. 2004. MEGA3: Integrated software for Molecular Evolutionary Genetics Analysis and sequence alignment. Brief Bioinform. 5:150-163.

24. Matsuda, S., and Takamatsu, S. 2003. Evolution of host-parasite relationship of Golovinomyces (Ascomycete: Erysiphaceae) inferred from nuclear rDNA sequences. Mol. Phylogenet. Evol. 27:314-327.

25. Noordeloos, M. E., and Loerakker, W. M. 1989. Studies in plant pathogenic fungi - II.
On some powdery mildews (Erysiphales) recently recorded from the Netherlands. Persoonia 14:51-60.

26. Oichi, W., Matsuda, Y., Nonomura, T., Toyoda, H., Xu, L., and Kusakari, S. 2006. Formation of conidial pseudochains by tomato powdery mildew Oidium neolycopersici. Plant Dis. 90:915-919.

27. Shi, A., and Mmbaga, M. T. 2006. Perpetuation of powdery mildew infection and identification of Erysiphe australiana as the crape myrtle pathogen in mid-Tennessee. Plant Dis. 90:1098-1101.

28. Shin, H. D., and La, Y. 1993. Morphology of edge lines of chained immature conidia on conidiophores in powdery mildew fungi and their taxonomic significance. Mycotaxon 46:445451.

29. Staden, R., Beal, K. F., and Bonfield, J. K. 2000. The Staden package, 1998. Methods Mol. Biol. 132:115-130.

30. Swofford, D. L. 2003. PAUP*. Phylogenetic analysis using parsimony (*and other methods). Ver. 4. Sinauer Associates, Sunderland, MA.
31. Szentiványi, O., Kiss, L., Russell, J. C. Kovács, G. M., Varga, K., Jankovics, T., Lesemann, S., Xu, X., and Jeffries, P. 2005. Ampelomyces mycoparasites from apple powdery mildew identified as a distinct group based on single-stranded conformation polymorphism analysis of the rDNA ITS region. Mycol. Res. 109:429-438.

32. Takamatsu, S. 2004. Phylogeny and evolution of the powdery mildew fungi (Erysiphales, Ascomycota) inferred from nuclear ribosomal DNA sequences. Mycoscience 45:147-157.

33. Takamatsu, S., Shin, H. D., Paksiri, U. Limkaisang, S., Taguchi, Y., Thi Binh, N., and Sato, Y. 2002. Two Erysiphe species associated with recent outbreak of soybean powdery mildew: Results of molecular phylogenetic analysis based on nuclear rDNA sequences. Mycoscience 43:333-341.

34. Vági, P., Kovács, G. M., and Kiss, L. 2007. Host range expansion in a powdery mildew fungus (Golovinomyces sp.) infecting Arabidopsis thaliana: Torenia fournieri as a new host. Eur. J. Plant Pathol. 117:89-93. 